\section{The Siyavula Case: Digital, Collaborative Text-Book Authoring to Address Educational Disadvantage and Resource Shortage in South African Schools}

\author{
Sarah Lambert*
}

$\begin{array}{ll}\text { Received: } & 28 \text { December } 2018 \\ \text { Revised: } \quad 15 \text { January } 2019 \\ \text { Accepted: } \quad 21 \text { January } 2019 \\ \text { ISSN: 1307-9298 } \\ \text { Copyright @ IEJEE } \\ \text { www.iejee.com }\end{array}$

DOI: 10.26822/iejee.2019349252

\title{
Abstract
}

Siyavula is known as a pioneer developer of high-quality free digital maths and science textbooks to address resource gaps and disadvantage in South African schools. This case study identifies the success factors which could be replicated in other contexts. Siyavula has developed expertise in digital developing, editing and improving maths and science workbooks and teachers' guides and distributing them in multiple digital and mobile formats for free. In 2013 the government took the free texts and sponsored the printing and distribution of c500K copies of Grade 4-6 titles, saving the government approximately USD\$83.5 Million for each of the 12 books (student workbook and teacher guide in both English and Afrikaans). The collaborative authoring system is identified as instrumental to the success of the project to address under-resourced schools, through a combination of personal (attitudinal), technical (online systems) and social resources (volunteers and stakeholders). Siyavula leaves a legacy of multi-stakeholder volunteer text-books sprints where an intense face-to-face experience provides the ground-work for constructive online authoring inclusive of diverse stakeholder input across different roles and ranks. Collaborative authoring advances curriculum and pedagogy sharing, expertise and capacity building. Collaborative authoring systems are found to have potential in many under-resourced school contexts not only for school texts, but also for early reading, multi-lingual and culturally appropriate book adaptations.

Keywords: STEM, Textbooks, Disadvantaged Schools, OER, Social Justice, Digital Resources, Mobile Friendly, Online Publishing

\section{Introduction}

Siyavula is known as a pioneer developer of high-quality free digital and print maths and science textbooks for South African schools. The work began in 2002 in response to personal interactions with determined kids from poor rural schools at a Science Fair seeking to overcome a lack of resources and science expertise in the schools including a lack of science textbooks.

By 2013 Siyavula had not only created a digital suite of Open Educational Resource (OER) texts downloaded by hundreds of thousands of learners, they had also built a relationship with government and had Grades 4-6 books printed and distributed nationally at no cost to schools. This benefitted a cohort of learners who would otherwise have had no textbook due to curriculum shifts and other external issues. The use of OER rather than commercial texts also saved the Government millions of Rand, as in addition to being free to the end-user, OER texts have no copyright restrictions limiting copying and distribution. OER texts are designed to be shared and modified by others as part of an effort to democratise access to knowledge and learning.

Siyavula developed a private-public partnership business model with philanthropic funds and voluntary labour covering textbook authoring, which reduced print and distribution costs of texts to approximately $14.4 \%$ of a similar commercial offering. They had developed a "one book, multiple formats" delivery system which allowed learners to download and learn maths and science topics with the most basic of "feature phones" and also got these resources "Z rated" so that the downloads were free - an important strategy in a context of high data charges which are a barrier to downloads. Siyavula was therefore able to address a lack of access to good quality maths and science resources which is a problem in many countries world-wide. Provision of free resources is a strategy to address the larger global problem of declining maths and science foundation skills, which tends to have a greater impact on poorer or more disadvantaged schools. Low-resourced schools tend to be caught in a downward spiral of fewer students studying higher levels of maths and sciences leading to fewer maths and science classes leading to fewer skilled and enthusiastic teaches. These factors all combine so that disadvantaged schools inadvertently perpetuate inequality of life chances by graduating whole cohorts who can never apply for let alone succeed in post-secondary education and high-status courses such as medicine and engineering (Mestan \& Harvey, 2013).

This South African case study offers insights of interest globally for a range of low-resourced school contexts, as keeping students from all backgrounds enthusiastic about and engaged with foundation science, technology, engineering and maths (STEM) learning is a strategic equity priority in many countries around the world.

Fundamentally, this case study aims to unpick the history and development of Siyavula and OER textbooks in South Africa so that others may learn from the experience. It focusses on how collaborative authoring processes enabled OER textbooks to be developed, and how South African school students were enabled by these.

The case study analysis identifies which of the success factors are unique to a particular moment in time in South Africa, and which might be replicated in other contexts. The study also probes for student uptake, impact and outcomes. It therefore offers a new perspective as well as a more comprehensive case write up than the few existing publications which look at early evaluations (Siyavula: Building Communities to Support Teacher Use, Localization and Sharing of OER, 2009), publication costs (Goodier, 2017), business models (Stacey, 2017), and teacher perceptions and usage (Pitt \& Beckett, 2014). 


\section{Background}

Although Siyavula was founded as a social enterprise in 2012 , by then the group had ten years' experience in collaborative digital developing, editing and improving maths and science workbooks and teachers' guides and distributing them in various digital forms for free.

Siyavula has developed a digital catalogue of OER STEM textbooks and other online practice resources providing students with quiz and feedback sequences. For each book in the grades 4-6 and 10-12 series there was both an OER student and teacher guide book, and each was printed in both English and Afrikaans.

By 2013 Siyavula had proved it was possible to transform learning resource provision to enable more equitable learning opportunities in South Africa - by using a blend of private-public-philanthropic resources and outputting using a blend of digital and print formats. But the political and policy context shifted before the exercise could be replicated let alone expanded within South Africa. However, due to a 2017 grant from Google, Siyavula has been able to migrate its successful OER concept-mapping and textbook work to neighbouring African nations, starting with Nigeria (Khan, 2017).

Parallel to the work on OER texts, Siyavula continues to develop low-cost but commercial digital learning tools for maths and science, and sponsors cover costs so the poorest school students can still benefit.

South Africa has around 25,000 schools and 12 million learners in the system. There are quintiles in terms of performance with Quintile 1 schools being severely under-resourced, ill-equipped and dysfunctional, and Quintile 5 schools being the top-end schools.

Mark Horner, Siyavula CEO notes, "Most of the (philanthropic) funders work in schools in quintiles 2-4 bracket, they probably won't have either running water or electricity. Probably they have pit latrines. The 350 schools who are sponsored for access to our practice service fall into this bracket - some of them are urban, some of them are rural. In quintile 5, the top tier, the independent schools, we've got about 75-80 schools using our subscription service and they pay us, but they will ask for the parents to pay for it."

Many of the processes, technologies and partnerships Siyavula developed continue to hold promise for future change in South Africa and beyond.

In particular, their pioneering collaborative authoring systems and their business models which support sustainable social enterprises stand out as having long-lasting value. In recent years there has been an interest in how to sustain open education projects. Other OER projects around the world have developed similar methods such as textbook sprints and blended business models to ensure the sustainability of their enterprises which have a social purpose. A recent book about open business models used many examples including Siyavula's organic development from experiment to grant to social enterprise (Stacey, 2017).

However until now the full details of Siyavula's success factors have not been published. This unique case study offers rich details about the personal, technical and social resources that underpinned Siyavula's success and legacy. If also offers a discussion of the potential of Siyavula's model and collaborative online systems for other contexts including for bi-lingual foundational reading skills and bi-lingual classroom instruction.

\section{Methodology}

Case studies are a regularly used form of empirical enquiry used in educational research, as they allow "how" questions to be answered by investigating complex contemporary phenomenon "in depth and within its real-world context" (Yin, 2009). The research question guiding the data analysis and write up of the case was: how did Siyavula develop an equitable and sustainable learning resource development system that delivered value to individual learners, schools and government?

Case study methodology was followed, focussing on the history of a single organisation as a unique case that can offer unique insights. The timeframe is $2002-2017$ and the context is South Africa. The primary data was a set of records provided by Siyavula including a verbal account of the history of Siyavula and OER in South Africa from the perspective of Mark Horner and Megan Beckett - two key and long-term Siyavula staff-members who had different roles and foci during the period as the following section explains. Using Google docs as a space to share documents and data from Siyavula's history, Mark and Megan were also able to provide clarifications on the materials in response to questions from the researcher. Human Research Ethics Committee approval was gained from Deakin University to conduct the research, including for naming the participants with their approval in the case study and for sharing the primary data sources in an open-data repository for the benefit of other researchers and future research (Lambert, 2018a).

\section{Mark Horner and Megan Beckett}

Mark Horner is CEO and Director of Siyavula and physics PhD graduate of the University of Cape Town (UCT). Mark led the first exploratory (2002-2007) Free High School texts development with other UCT colleagues after meeting the township kids at the Science Fair. Mark has led all subsequent work firstly funded by the Shuttleworth Foundation and later as Siyavula spun out of that structure as a separate company.

At the time of writing, Megan Beckett was responsible for Learning Research and Analytics at Siyavula. Megan joined Siyavula in 2011 and led the development of the Natural and Life Science textbooks, starting with the year 4-6 curricula which was printed by the South African Government. Megan was instrumental in the iterative development and refinement of new processes of community engagement in the development of quality, curriculum aligned texts. This involved physical and virtual contributions from teachers, curriculum experts, technical experts, students and government officials. Megan left Siyavula in 2018 to launch her own consultancy company.

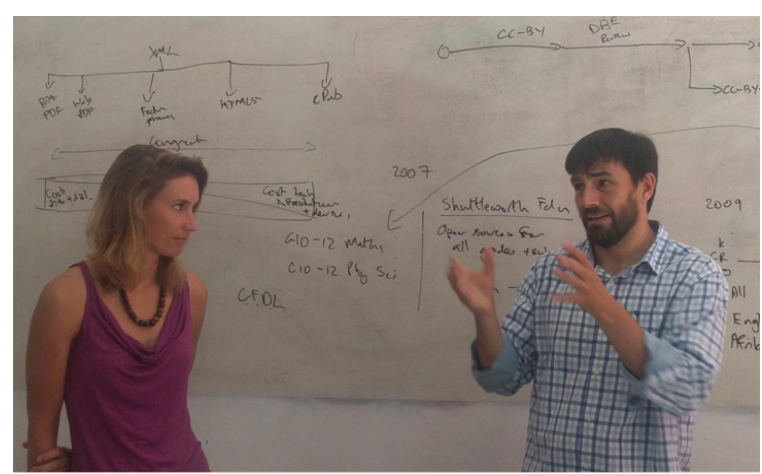

Figure 1. Megan Beckett and Mark Horner at Siyavula office, March 2017 (CC-BY Sarah Lambert) 


\section{Data Analysis}

The case study analysis and write up was undertaken by the author in the light of research developments, interests and insights which have emerged from a related PhD study in the area of open education as social justice actions (Lambert, 2018b). The case study was influenced by an interest in research methodologies that seek to identify success factors with transferability to other contexts, and insight into the use of social enterprises to sustain open education work for the benefit of low-resourced communities.

The data that the author has relied on to address the research question and interests are the components of Mark and Megan's verbal accounts focussed on key developments and events leading to the 2013 milestone achievement and the reflections on the long-term value of developed processes in the light of the contextual changes. Accordingly, some of the more technical information captured in the original data eg xml pipelines to multiple publishing formats are not discussed in detail. Researchers with complementary research interests in the Siyavula case are encouraged to review and use the original data logs (Lambert, 2018a) to further their own research.

The case has been written up using time as an organising device. The key developments and events appear under a heading of the year in which they occurred. The sections are enriched with direct quotes from Mark and Megan to provide both facts and the tone or feeling of the events. The aim is to let Mark and Megan describe key events in their own words wherever possible so that their considerable contribution is not overshadowed nor skewed by the researcher or the case write-up. Each year section ends with a discussion of the case themes, identification of unique versus replicatable actions and events, and comparison with other recent similar work. Next, an overview of all the case themes is provided classified by Warschauer's dimensions for socially inclusive uses of ICT: Technical (Physical/digital) resources, Personal resources (called "Human" by Warschauer, and here extended to include attitudinal resources), and Social resources (Warschauer, 2003).

The case concludes with a discussion of the legacy and potential for future work both within and beyond South Africa.

The Siyavula Case: Success Factors that Made Excellent Maths and Science Learning Accessible and Affordable in South Africa

\section{University of Cape Town Science Fairs}

Mark Horner was one of the graduate students at the University of Cape Town who ran physics demonstrations at community-based Science fairs which brought him and colleagues into contact with "barefoot" physics students learning without textbooks or teacher expertise. Mark said this experience led to the development of a "project started by graduate students called Free High School Science Texts to collaboratively author text books."

"We had had kids come to our Physics demonstration at a Science fair, (they'd) seen something that was in the curriculum, they'd come back the next day with a notebook and a pen, and they'd ask if they could write everything down. They were often from a really poor rural school, they said they didn't have textbooks and their teacher wasn't going to be able to teach it to them, but they knew it would be in the grade 12 exam at the end of the year. So they'd write everything down. These are barefoot kids, grey flannels and a white shirt, but barefoot."
With the back-drop of the Science Fair, what stands out from Mark's account as the catalyst for action was the personal interaction with individuals - with those barefoot kids from those poor rural towns. And it wasn't just a matter of feeling sorry for them. I suggest from Mark's account there is also a sense of being impressed with these kids' determination to succeed. Not only did these kids make an effort to come to the science fair, they also knew enough about the curriculum and the end of year examinations to know what knowledge they were missing. This motivated them to come back for a second day and take down all the notes that they could. This is an excellent example of learner agency - the ability to identify and solve their own problems to meet their own goals (Archer, 1996, 2003; Case, 2013). When learners are this motivated and capable, it is reasonable to think that effort to give them assistance through provision of a decent textbook might actually make a difference.

Equity research calls this working from a "strengths perspective." Strengths approaches continues to gain ground with equity researchers and practitioners in contrast to a "deficits approach" which has been shown to be problematic over the last decade (Devlin, 2012; McKay \& Devlin, 2015; Mountford-Zimdars et al., 2015; O'Shea, 2016; Southgate \& Bennett, 2016). A "deficits approach" to helping disadvantaged learners stems from the perspective that learners are lacking in ability, motivation, family support and/or community role-models. This tends to perpetuate low expectations and remedial approaches which not only re-inforces disadvantage but also limits the effectiveness of the work (Atal, 1997; Munns, Sawyer, \& Cole, 2013; Thomson, 2002).

I would argue that Mark and colleagues' early engagement with these poor but resourceful community learners at the Science Fair not only personalised a group that are often reduced to a stereotype or impersonal cliché. But it also seeded a strengths-based approach based on respect and faith in learners and is a core success factor that underscored this particular catalysing event. The themes of personal engagement with community and of learner strengths and agency are important that will appear again and are threaded through the case study.

\section{2-2007: Free High School Science Texts (FHSST) project}

Over a period of 5 years, Mark and a tech savvy group of physics graduate students volunteered their labour to collaboratively develop free OER maths and science textbooks for school grades 10-12. Because of their experience in open-source software community, they were aware of the early alternatives to copyright ie licences that allowed sharing. They would ultimately adopt what has become an international standard: the Creative Commons licencing system (see https://creativecommons.org/).

5 years is a long time to maintain momentum and voluntary commitment for such a project. This may be a unique or rare occurrence compared with other projects in other parts of the world which rely on grant funding to develop free resources (Lambert, 2015) or paid post-graduate students working on university level materials (Hodgkinson-Williams \& Paskevicius, 2012).

The ability to keep the project going over 5 years seems to be related to the importance the graduate students placed on the work, and the fact that a whole group was involved. While there may have been a small core authoring team, at final count there were 40-50 contributors on each textbook. So too were strong computing science skills needed to manage the technical production. Considering the well documented challenges with collaborative work, the success of this sustained 5 year effort might be linked to the 
collaborative authoring strategy - working within strong and functional existing collegial networks with strong existing technical skills, and on the basis of writing subject matter which is well known to you.

Their technical background and exposure to open-source software also shaped the approach. They side-stepped a debate over the definitions of the terms "free" and "open" (the latter connected to specifics of legal licencing options) by pragmatically focussing more on educational equality than making a commitment to "openness".

"The project has this extremely unimaginative name, just because of the complexities of dealing with people in the free software movement ... And we are very pragmatic... Eventually, they didn't care if you used the word free, so we went with the Free High School Science Texts, a descriptive and pragmatic and boring name. We called it an open text at the start, and they were like, "hmmmm is it the right kind of open?" And we were like, we don't really care. The need we were trying to address is kids who don't have access to textbooks."

During this time many people and organisations invested time and resources into developing coherent series of free or open educational resources (OER) FHSST would go on to be re-purposed and re-used for different cohorts and purposes, and others such as the Saylor.org, OpenStax textbooks or MIT Opencourseware content formed the basis of many early MOOCs. Repositories designed to share or globally distribute free learning resources like MERLOT (more for teachers) and iTunesU (more for the individual learner) were also emerging and gaining momentum. Unlike these examples which are mostly authored by wage-earning higher education earners, Siyavula stands out for the degree to which they were able to harness volunteer graduate student expertise. There is some common ground however - they have shown over time that investing in quality series of curriculum aligned OER is a good investment which can bear fruit many years after the original effort.

2007: Shuttleworth Foundation and the Cape Town Declaration of Open Education

In 2007 a meeting of OER leaders organised by the Shuttleworth Foundation authored and signed the Cape Town Declaration of Open Education. Concurrently, a project was launched that hired Mark to expand the FHSST project. The project was called "Siyavula" and it was ambitious. The goal was to collaboratively author OER school texts for all grades, and all subjects. Siyavula means "we are opening". Siyavula's mission is to make excellent maths and science learning accessible and affordable for all. During this period, it also aspired to transform publishing models as a way to increase equitable educational access.

\section{7-09: Siyavula Project acquires pre-existing textbook con-} tent

During this period Siyavula purchased pre-existing textbook content for Grade 0 (eg Kindergarten) to Grade 9 for all Learning Areas, in both English and Afrikaans. The idea was always to build a community of users around the content, but during this period Mark realised there were 2 ways this could be done - collaboratively author from scratch, or collaboratively modify based on some existing content. The latter choice of strategy to engage teachers to review and modify a base set of resources addressed both the desire to scale up the project quickly and to also deal with the identified problem of cultural resistance for sharing maths and science teaching resources in South Africa.
"If you bring a community together and you ask them to share their resources, particularly in a unhealthy and very critical environment like we do in South Africa for teachers then they are very scared to share, because it can expose their competence or lack thereof, they can feel like they are gonna be attacked, they can feel like it's a form of assessment. So there's a lot of issues around the sharing." "So our theory of change was that we could bring this content, bring communities or groups of teachers together, to use this as non-threatening content that they could adapt and enhance. You've probably seen this, if somebody takes a resource and they make a tiny tweak, they fix a typo in a book, and it's like they've written the whole book all of a sudden, a sense of ownership."

"Ownership" by engaging in authorship of resources is important, as it tends to lead to increased awareness, advocacy and use of the resource. Following this logic, a point of difference for Siyavula emerged - the more authors the greater the take-up and the greater the return on that time and resource investment.

Also, these quotes show that by this point Siyavula had conceptualised of their project as more than a textbook project, and had developed a "theory of change" in line with many other resource-constrained and poor-performing education systems (Daniel, 2014; Laurillard, 2016; Patru \& Balaji, 2016). They wanted to improve teacher skills and pedagogy at the same time as improving the actual resources.

2009-2010: Mass staff training to modify draft textbook content using Connexions platform

During this period, Siyavula put the acquired content on the Connexions online textbook platform and attempted to train 1000 teachers and curriculum advisors in online authoring, many located in remote and rural locations. This was a major undertaking involving the use of portable internet servers and wifi networks and a suite of 100 laptops. Despite best efforts - it was not successful.

Mark notes - "I love the Connexions team, we've worked with them for many years, but their website is un-usable by teachers. It's too complicated, we tried, we wrote manuals, we taught them basic xml, but as soon as people see mark-up languages they're freaking out. It didn't work. They want to use Word."

The original materials are still on the original Connextions platform and Megan notes that "there was some uptake and adaptation of the content by teachers, but not to the scale that was initially envisioned nor in line with the number of teachers actually trained."

This tough reality check about what technological tools non-technical experts are prepared to accept and use was a lesson learnt the hard way by others as well as Siyavula. For example, wiki authoring never made it to the mainstream despite many efforts as Wikipedia rose to prominence and innovative educators began to embed it in lessons and assessment. Lack of technical skills to modify and localise OER has been a real barrier to OER adoption across the board (Wiley, Bliss, \& McEwan, 2014). There is a tendency to look at IT training as a matter of breaking down tasks required of the software, and making each of them as simple as possible. In reality users want to invest time in learning to better use the tools they use everyday, across numerous tasks and domain rather than spending time on specialist tools that have high skills barriers to entry, and which they will not in reality use very often. This is a factor with other educational technologies such as LMS and ePortfolio tools, which students typically do not use once in the workforce. 


\section{0: Public Sector Strike and an early text-book sprint}

In 2010 there was a major national Public Sector Strike in South Africa over claims for reasonable wagen and housing allowances. The striking public servants including teachers and nurses had been campaigning for many years but were resolved to strike because after "the government's lavish expenditure on the 2010 soccer world cup, strikers found it difficult to believe that government could not meet their demands." (Ceruti, 2011). The large and powerful teachers' union went out on strike early, and stuck it out so that kids were without teachers for about a month. The Department of Education seized upon the openly licenced FHSST texts to mitigate the loss of teachers and teaching time for year 12 students approaching final exams with no teachers.

"So they called, literally phoned one day to ask can they print this stuff for the whole country, to try and mitigate the effects of the strike... This was the trigger for them to consider these open resources as something that they could use..." While the printing of books turned out to be beyond the Government's budget at that time, the crisis surfaced extra voluntary labour to edit and improve the digital versions. As Mark notes, "So we did some things that were quite interesting. We edited all 6 books in the space of one week using 100 volunteers collaborating online. They said can you just do another proof-read, and we said, well, that's a few thousand pages of content. We got Mark Shuttleworth to put a call out on his blog, for people to help us. And we got people with a Masters or PhD to help proof-read the content. 100 people who are prepared to proof-read a few chapters, can get through a lot of content very quickly because they're distributed, and it's all happening online simultaneously, with online annotation." The public sector strike - a unique point-in-time and place event was critical to Siyavula's development as they were able to gain traction with the government regarding OER texts, and yet is not something that can be manufactured. As Mark notes, "This is only relevant because some people would like us to be a success story that can be replicated... there were a lot of people who thought what we did could be replicated but there were a lot of factors that were way out of our control."

It also shows the power and goodwill of volunteers to step-up when needed to edit 6 books in a week via online collaboration. What is less clear is if these (or other) volunteers would have put in the time if they thought the books would not be printed. Volunteer motivation to see a concrete output from their work can be first seen in this early 'book-sprint' and will also emerge later in the case.

\section{1: new working relationship with the Government}

The FHSST texts were curriculum aligned to the 2005 curriculum statement and naturally, over time, the curricula was reviewed and changed. The new 2011 curriculum was tightly defined with regard to topic teaching sequence and timing. The new curriculum was both more supportive and more prescriptive of what was to be taught. This was because teachers' skills in translating the older outcomes based curriculum materials to actual lesson plans was not considered to be sufficient in practice due to lacks in staff training and development. The new curriculum meant textbook providers had to meet stricter government requirements regarding both the format and the content. The new curriculum made the FHSST redundant and so in 2011 Siyavula took their Grade 10 maths and Science books, aligned them to the new curriculum and got them approved by what had become the Department of Basic Education (DBE)
This phase of the case signalled a developing of a productive working relationship with the government which had formed during the public strike action period.

Importantly, these books were printed, and Siyavula's first free open textbooks went into government schools in 2012. Because the Siyavula website URL was printed on the books' covers, the books also drove students to the website for digital versions. Google Analytics indicated a massive burst in website traffic. Mark clarified that when these books were printed "we were getting 500K unique visitors to the website per month, a huge amount. That's about $30 \%$ of the kids in that grade in the country. But the government distributed it late so a lot of the kids were reading it online, and $40 \%$ were reading it on feature phones."

The collaboration with the government was not limited to approving the completed textbooks. Government officials were involved in the face-to-face text-book sprints which Megan began to use in 2011 to author her new series of books from scratch.

From 2011 the collaborative authoring models were developed further to embrace both face-to-face book-sprint workshops and virtual collaborators. For the book-sprints which ran over 3 weekends, Megan and the Siyavula team provided plenty of preparation and structure - including the development of curriculum maps showing how skills built on each other over Grades 4-6. The curriculum maps turned out to be a significant resource that engaged the development and authoring community in constructive conversations and negotiations about science pedagogy. When combined with the online authoring environment, particularly the annotation and commenting tools, they served to break down barriers between collaborators of differing rank or status - collaboration was more free flowing between classroom teachers, curriculum expert or government officials.

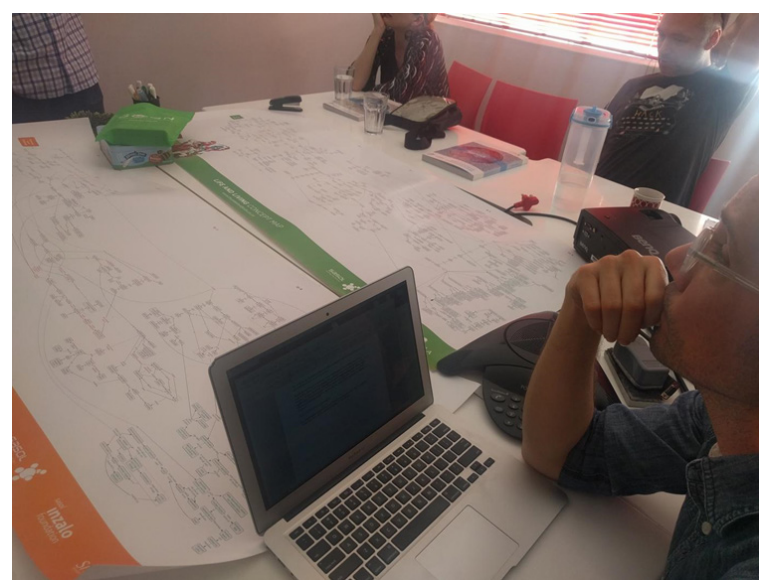

Figure 2. Curriculum maps showing learning outcomes across the years became important planning tools and also social resources that fuelled the collaborative textbook authoring process (CC-BY Sarah Lambert)

The collaborative authoring process developed over time to be a blended face-to-face and online process. Megan recalls that "initially we tried to author everything within these physical workshops, but realised the real value came from the brain storming discussions...and their ideas and practical experience of what works in the classroom, so we focussed the physical workshop on discussing this in depth and collecting all these ideas."

Siyavula decided to hire professional authors to write the books based on the workshop notes with input from other teachers and experts online. Later they hired a commu- 
nity co-ordinator who would assign online tasks such as proof-reading or translating to keep things moving along. See Figure 3 for a diagram of the new collaborative authoring model. The model helped transition a core group in a physical environment to a functioning virtual group authoring text-books.

Mark notes that having a couple of paid people doing key tasks of writing and co-ordinating actually makes volunteers feel more confident to donate their time on the project, as they are sure that there will be a useful outcome. And "so it becomes easier to recruit volunteer expertise in content authoring."

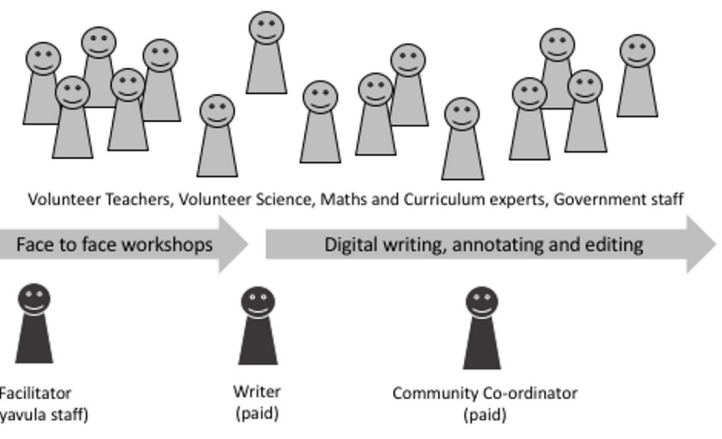

Figure 3. Siyavula's modified 'book-sprint' collaborative textbook authoring process (CC-BY Sarah Lambert)

The collaborative authoring process was also shaped to bring in a diverse range of volunteers from around the country, for the purpose of shaping the most inclusive and relevant book for both city and regional South African learners.

As Megan notes, "for the Joburg workshops, we flew up some teachers from different provinces, even one teacher from a township school in Gugulethu. Although it is not possible to make one book that will satisfy all the needs of all teachers and learners in a country, especially one as diverse as South Africa, if we have multiple, diverse voices taking part, we can strive to make content that is inclusive and representative of our country." Siyavula's intent to include diverse author's views and local context can be considered both recognitive and representational social justice actions (Lambert, 2018b).

2012: first free textbooks printed and distributed, saving the government millions

By the time Siyavula had its first free open textbooks into government schools in 2012, the magnitude of cost savings for the government became quantifiable, and real.

The Siyavula Grade 10 texts were printed and distributed. While government records are not totally clear, it seems that around 10 million books were printed and distributed to schools nationally (Goodier, 2017). A comparable text from a commercial publisher would be 250 Rand per unit printed and distributed but a Siyavula text would cost approximately 36 Rand per unit. Based on these figures then, Siyavula's model produced a run of textbooks at only $14.4 \%$ of the commercial costs which translates to 107 Million Rand in savings per text-book title with a print-run of $500 \mathrm{~K}$ units. At the exchange rate at time of writing, this is 10.3Million AUD and 7.4Million USD.

Having succeeded to get Grade 10 ie High School maths and science texts printed and distributed to schools, Siyavula next authored the Grade 11 books to the new curriculum standard and expanded their publishing formats for access via mobile devices which are more commonly used that laptops in South Africa.
2011-2 showed that the maturing collaborative authoring systems were agile enough to facilitate major book modifications after curriculum change. Developing free OER texts aligned to curriculum relevant to and needed by disadvantaged learners is another success factor shared by Siyavula and other OER developers such as the Open University UK (Law, 2015).

Megan Beckett also embarked on a major project to develop Science textbooks for the primary school - Grades 4-6 Natural Sciences and Technology curriculum. As Megan notes, "We were approached by the DBE, along with a partnership from the Sasol Inzalo Foundation, to do this project. The Sasol Inzalo Foundation provided the funding for the development and production of the books, in print, ePub and online. And the DBE used a "Special Projects" budget to pay for the printing and distribution."

Siyavulas technical "pipeline" had matured so that they could output to numerous technical formats from the one source of textbook content, as Figure 4 shows below.

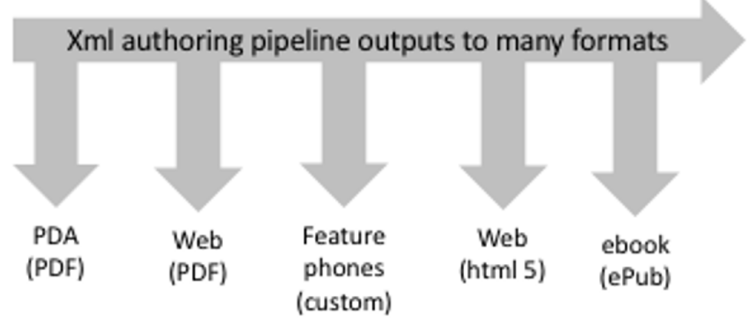

Figure 4. Siyavula's xml authoring system was a key technical resource with the ability to output to many formats (CC-BY Sarah Lambert)

\section{2: Siyavula becomes a company}

In 2012, at the conclusion of the Shuttleworth funding, Siyavula became a company and social enterprise. Their new business model still involved cost-recovery from sponsors for textbook development, and value-added for-fee online practice services for schools and learners. These services were also sponsored so the poorer schools and learners could participate.

This was a year before David Wiley and Kim Thanos founded Lumen Learning in the US, which has some parallels to Siyavula not only in their mission to work with OER for disadvantaged learners, but also with regards to collaborating with a major funder. Lumen's early work was funded by The Gates Foundation who required them to develop a sustainable business model prior to receiving additional investment to expand their early pioneering work customising OER texts (Stacey, 2017). Where as Lumen's business model would target Higher Education institutions to pay for custom services, Siyavula looked to schools and individual learners to pay for value-added services. While both need income to sustain activity, both also put social good before profit, were seeded via philanthropic funding, and continue to provide free digital OER as a baseline service.

2013: National distribution of OER texts fills the void for 3 million learners

In 2013, Siyavula OER textbooks peaked in South Africa. The Grades 4-6 Natural Sciences and Technology work books were printed and distributed such that $100 \%$ of government schools nationally received free copies of printed OER textbooks. Approximately 6 million workbooks and teachers' guides were distributed to around 3 million learners - in 2 volumes per year. 
This was despite an independent curriculum review and subsequent changes to the curriculum late in the authoring process. No commercial publisher's books met the criteria for the new curriculum given the late curriculum changes. Megan and Siyavula's online authoring systems however, got the job done.

"A month of all-nighters and Megan managed to get this stuff up to speed, but the other publishers weren't able to. So these resources actually saved an entire cohort from having no educational resources for science for one of their subjects - that's about 3 million kids" notes Mark.

In 2013 Megan also led the production of the Grade 7-9 Natural Sciences workbooks, a Life Sciences Year 10 book and a Maths literacy Grade 10 book. Disappointingly, while they got approved, neither of them were printed or distributed due to shortfalls in the Minister's special projects budget.

Regardless, Google Analytics from the time indicate huge spikes in online traffic to the Siyavula website - approximately 500, 000 students were downloading the texts per month.

Learner agency and motivation was again evident in the Google Analytics massive number of downloads from those prepared to teach themselves via free online textbooks. Some were also able to use the online practice service. Many of the learners had no access to laptops or desktop computers, but nevertheless were reading texts on their low-tech feature phones.

By this time there had been continuous improvement over many years in both the quality and efficiency of Siyavulas' collaborative text-book authoring system. Book design, layout, pedagogy, and production methods had all improved.

The dedication and commitment of Siyavula staff to the work, and the commitment to improvement of systems are success factors which whilst not unique in a successful business, can be hard to achieve. Underpinning such commitment is the stability and continuity of key staff over the years and this is in contrast to the current trend for the "gig economy" or casualization of knowledge workers who are increasingly employed on short contracts with no certainly or stability. Such terms of work do not foster loyalty, commitment or going above and beyond.

\section{4: Post election change in textbook policy direction halts progress of OER texts}

In 2014, Siyavula was poised to really shake-up text-book provision for South African schools. Their production model and systems had matured and they had big plans. They hoped to produce an OER catalogue of 42 titles covering all learning areas from Grade 4 to Grade 12 for the whole country.

After the election however, the in-coming Minister for Basic Education signalled an intention for major changes to textbook policy. To save funds they proposed a central procurement of a single textbook for each grade/subject/ language combination for the country. OER texts were also mentioned as a possibility. As Mark notes, this was "announced in her post-election speech. And that threw the entire publishing sector into turmoil." The government needed to change legislation for this to happen, by amending the Schools Act. However, they were unable to do so leaving the publishing industry - both OER and commercial - in limbo for over 3 years. At the time of writing this case, the uncertainty which halted all progress or work on OER texts had still not been resolved.
Sadly for Siyavula and OER texts in South Africa, avenues to continue OER production with funders dried up. As Megan notes, "we still pursued the idea for most of 2014, trying to see what would work, but in October 2014, a high-level strategic decision was made not to continue with the OER work."

The government policy shift was a second major political event that impacted Siyavula and could not be predicted or manufactured. Unfortunately, unlike the public sector strike which enabled OER texts to solve a difficulty problem, the impact of this policy change was negative and no workarounds could be found. The stalemate meant that funders' involvement was either financially risky, or ethically and reputationally risky.

Mark notes: "All the funders we were talking to about this 42 title expansion said to us: Are we sponsoring a book that will never be used, because it's not going to be THE chosen book. Or are we sponsoring state publishing? And both of those are undesirable scenarios....So that's sort of where our OER stuff fell in a bit of a heap."

The death of promising educational technology projects due to changes to policy, funding or resourcing are relatively common or at least anticipated events post-elections events within all levels of the education sector - particularly when governments are predicted to change. However the 2014 turn of events for Siyavula seemed particularly shocking in the light of their success and incredible cost savings to government just the year before.

Regardless, the online services continued to grow and in 2014 Vodacom (major internet provider in South Africa) first zero rated their website and resources, so that no Vodacom mobile user paid data to access the services - a major boost for disadvantaged learners.

2014-2018: OER texts out of circulation, commitment to digital services

With avenues for further OER textbook production closed, Siyavula made the decision to focus on their digital, personalised or "adaptive" practice service which is now called "Siyavula Practice." Mark says: "It supplements the content in the (free online) books and enable a learner to choose topics that they'd like to practice until they've mastered them." They continue to work with supportive sponsors so that poorer schools can use the service.

Mark feels that there is potential to bring back collaborative authoring in South Africa and work with Faculty to contextualise other open books. Also, funders might be able to provide poorer, regional kids with a kindle or similar low cost e-reader with long battery time. Importantly he notes, "you don't need power at home to read it. It would take one charging station in the school, as the charge can last 2-3 weeks. So kids could charge at school and take home and read where they have no electric light, for our context."

While it became impossible to reprint and restock the earlier OER texts, older versions still circulated adding to the demand for digital versions which remain strong. Website traffic remains very high every year, particularly as Siyavula negotiated with MTN or Vodacom (the two biggest service providers) so learners can download the materials without incurring internet data charges.

Megan notes that "this has helped break down a huge barrier to accessing our OER content, as data charges are really high in South Africa, relative to other countries, and learners have very small amounts of airtime/data at their disposal, which they are less inclined to use on educational material." 
Table 1. Replicatable success factors as case study themes

\begin{tabular}{|c|c|c|}
\hline Year & $\begin{array}{l}\text { Case themes, replicatable success } \\
\text { factors }\end{array}$ & \\
\hline 2002 & $\begin{array}{c}\text { Personal engagement with local } \\
\text { community members reveals a need; } \\
\text { Recognition of learner strengths and } \\
\text { agency }\end{array}$ & Personal \\
\hline $2002-07$ & $\begin{array}{c}\text { Motivated voluntary labour (post-grad- } \\
\text { uate science students); } \\
\text { Collaborative approach to authoring } \\
\text { with a group of peer volunteers; } \\
\text { Strong computing science skills within } \\
\text { the voluntary group; } \\
\text { Exposure to open-source software; } \\
\text { Pragmatic valuing of 'free' over 'open' } \\
\text { (social justice values); } \\
\text { Awareness of lack of teaching exper- } \\
\text { tise; } \\
\text { Sought collaboration to ensure } \\
\text { curriculum alignment. }\end{array}$ & $\begin{array}{c}\text { Social } \\
\text { Technical } \\
\text { Personal }\end{array}$ \\
\hline 2007-09 & $\begin{array}{c}\text { Recognition of teacher risk in sharing } \\
\text { imperfect personal teaching resources; } \\
\text { Purchase of 'non-threatening' pre- } \\
\text { existing publishers' texts as a basis } \\
\text { for safe collaborative authoring with } \\
\text { teachers; } \\
\text { Theory of change developed - improve } \\
\text { pedagogy and teacher capacity while } \\
\text { creating and improving resources } \\
\text { together. }\end{array}$ & $\begin{array}{l}\text { Personal, } \\
\text { social }\end{array}$ \\
\hline 2009-10 & $\begin{array}{c}\text { Abandon unsuccessful technical train- } \\
\text { ing in teacher xml textbook authoring; } \\
\text { Recognise that it is legitimate for } \\
\text { teachers to want to use everyday tools } \\
\text { ie Word; } \\
\text { Teachers invest time in learning to } \\
\text { better use everyday tools for new } \\
\text { purposes. }\end{array}$ & $\begin{array}{l}\text { Technical, } \\
\text { social, } \\
\text { personal }\end{array}$ \\
\hline 2010 & $\begin{array}{l}\text { Volunteer authoring network acts as } \\
\text { resource that 'steps up' in times of crisis }\end{array}$ & Social \\
\hline 2011 & $\begin{array}{l}\text { Leverage crisis/change to build a rela- } \\
\text { tionship with government; } \\
\text { Constructive collaboration with } \\
\text { government post- crisis; } \\
\text { Blended text-book authoring process } \\
\text { (face to face workshops, online editing); } \\
\text { Curriculum maps of outcomes across } \\
\text { year levels a key resource for teacher } \\
\text { engagement at workshops; } \\
\text { Hire paid authors to write up the } \\
\text { workshop ideas; } \\
\text { Recognitive and representational social } \\
\text { justice provides "diverse voices" from } \\
\text { regional teachers of all ranks in the } \\
\text { development of textbook }\end{array}$ & $\begin{array}{l}\text { Social } \\
\text { Technical, } \\
\text { social } \\
\text { Social } \\
\text { Personal }\end{array}$ \\
\hline 2012 & $\begin{array}{l}\text { Maturing authoring platform for } \\
\text { efficiency, multiple output formats and } \\
\text { agility to late curriculum changes; } \\
\text { Hybrid business model - free mobile } \\
\text { friendly texts and for-fee online prac- } \\
\text { tice exercises with feedback; } \\
\text { Expansion of philanthropic business } \\
\text { sponsors to ensure poor students can } \\
\text { use online services. }\end{array}$ & $\begin{array}{c}\text { Technical } \\
\text { Technical } \\
\text { Social, } \\
\text { personal }\end{array}$ \\
\hline 2013 & $\begin{array}{c}\text { Recognition of learner agency and } \\
\text { motivation to download and learn from } \\
\text { free digital resources; } \\
\text { 'Zero rate' online resources so learners } \\
\text { don't pay mobile data charges } \\
\text { Create an environment for long-term } \\
\text { stable, dedicated staff to stay the } \\
\text { distance. }\end{array}$ & $\begin{array}{l}\text { Personal, } \\
\text { social } \\
\text { Technical } \\
\text { Personal, } \\
\text { social }\end{array}$ \\
\hline
\end{tabular}

\section{Summary of case themes}

Siyavula is a unique case study of a successful educational innovation that relied on a community of stakeholders including voluntary authors, systems and expertise to manage and lead that community, and a backbone of ICT systems and expertise that allowed the books to be created in multiple digital and print formats. While the ICT or technical components were necessary, the personal or human resources and social aspects were also absolutely crucial. In particular, the Siyavula case highlights what Warschauer refers to as "Social resources" ie the community, institutional and societal structures that support access to ICT in socially inclusive ways. In fact, all of Warschauer's (2003) required components for socially inclusive uses of ICT are evident in the case themes: Technical (Physical/ digital) resources, Personal resources (called "Human" by Warschauer, and here extended to include attitudinal resources), and Social resources. The values, approach or attitudinal aspects such as recognising learners' strengths and acceptance of teacher's legitimate choice regarding their role in the project are outstanding components of the "personal resources" that Mark and Megan brought to the work.

These are lessons that could be expected to have utility in other low-resourced schooling contexts. Table 1 above summarises the many replicatable success factors (case themes) which were crucial to the success, longevity and sustainability of the work. These are categorised by Personal, Social and Technical - and the themes are evenly spread between the three categories. This highlights the way in which ICT "does not exist as an external variable to be injected from the outside to bring about certain results. Rather, it is woven in a complex manner into social systems and processes (Warschauer, 2003, p. 8)."

In addition to the wide ranging replicatable success factors, there were also three unique and unreplicatable political events that shaped the trajectory of the project, as noted in Table 2 below. These relate to funders and government policy. In other contexts it is therefore recommended to plan to find ways to locate philanthropic funding particularly in the early phases of work, and in later phases to work constructively with Departments of Education ie governmental contexts.

Table 2. Unique events as un-replicatable factors as case study themes

\begin{tabular}{cc}
\hline Year & $\begin{array}{c}\text { Important events contributing to } \\
\text { project direction and eventual success }\end{array}$ \\
\hline 2007 & $\begin{array}{c}\text { Shuttleworth Foundation funded event in Cape Town } \\
\text { leading to the Cape Town Declaration of Open Educa- } \\
\text { tion, and the funding of what would become known as } \\
\text { "Siyavula" }\end{array}$ \\
\hline $2010 \quad \begin{array}{c}\text { Public sector strike in South Africa, all teachers were } \\
\text { off work for around a month leading up to the end of } \\
\text { year exams }\end{array}$ \\
\hline \multirow{3}{2014}{$\begin{array}{c}\text { Incoming Minister of Education policy decision on } \\
\text { central procurement of one textbook halted all text- } \\
\text { book development, both commercial and OER, leading } \\
\text { to refocussing on digital services and exploring new } \\
\text { opportunities }\end{array}$} \\
\hline
\end{tabular}

\section{Discussion of Legacy and Future Possibilities}

This case has shown the depth and breadth of the Siyavula legacy for South African schools and learners. Siyavula had developed: a "one book, multiple formats" collaborative authoring and online publishing system; a private-public partnership business model with philanthropic funds and both paid and voluntary labour; a way of working with Government and internet providers so that STEM texts reached disadvantaged and under resourced learners and teachers throughout South Africa.

Siyavula had developed processes and tools that supported a new multi-stakeholder collaborative textbook production model that was neither text-book sprint (face to face) or digital community - but a blend of the best part of 
both models. This production model proved itself as superior to comparable commercial methods for the South African market in terms of both efficiency (cost savings) and agility (responding to late curricula changes and political moves.) It proved itself at least comparable to commercial text in terms of finished textbook output quality. They had saved the government roughly 1,200 Million Rand in textbook provision costs to public school in 2011-13.

According to recent research, "open-business models" like Siyavula's social enterprise can shift the balance of power and influence between government, the market and "the commons" (Stacey, 2017). The commons is a long-standing concept that includes publically owned natural and built resources which are shared and managed for the common public good. This includes land, air and water, footpaths and parks, and more recently the "digital commons" which includes knowledge that remains free and in public control.

In applying this concept to Siyavula and its legacy, we can see that despite significant positive outcomes, what had not changed was the balance of power and influence between government, the market and "the commons" in the South African educational resource sector. While Siyavula have certainly enriched and expanded "the commons", a problematic inequality of access to current print resources continues to compound a history of inequality, and the current reliance on old procurement systems for expensive commercial texts is still a reality in South Africa.

New digital services offer promise but are still relatively new and the impact on learners' success is yet to be researched. Because digital tools tend to be first adopted and therefore primarily benefit the more advantaged sections of society (Engstrom \& Tinto, 2008; Selwyn, 2013) maintaining and expanding funding and supports for the newer digital services to the poorer learners, schools and communities is an area for future attention and research. In reflecting on the lack of systemic resource provision transformation, Mark calls the 2013 milestone of 100\% of government schools getting printed open textbooks "a bittersweet achievement. So great that everybody has a textbook which is open, but it didn't fundamentally transform anything."

\section{Ongoing benefit of distributed textbooks}

Regardless of the print production and textbook procurement systems not shifting, the digital versions do continue to be used. The common-sense argument reasonably suggests that having access to a digital textbook is going to be an improvement on having no textbook.

Some teachers surveyed regarding the impact of Siyavula textbooks backed this up (Pitt and Beckett, 2014). Teachers noted that students were able to leave hard copy textbooks at school, and access a digital version on their smartphones at home. They were more able to make use of class-time to do their homework because they always had a digital copy of the textbook on their smart phones. Not needing to carry around heavy textbooks between home and class, and not having to worry about lost textbooks were noted many times. Another teacher noted that underperforming students' results had lifted, and another teacher who had tracked exam results over the course of a year claimed students grades had improved. Lastly, there was a long-term benefit of retaining access to previous years copies to help with their final Year 12 "matric" exams. This is important as much of the Grade 11 syllabus is examinable at the end of Matric (Pitt and Beckett, 2014). While such research provides insight into how Siyavula books - both in print and digital versions - enabled learning in classrooms and at home, the survey respondents were dominated by private school teachers who were typically in better resourced schools and areas (Pitt \& Beckett, 2014). There is thus far no research looking at student outcomes across all the schooling disadvantage "quintiles." It is also not clear the extent that the textbooks help learners in their end of year exams or as preparation to succeed in higher grades. It is also not clear the extent that the digital texts (and the physical texts for the 2011 . 2013 cohorts) might have had an impact on international skills scores which are tracked over time. Considering the scale of Siyavula's reach for learners over multiple years, it is possible that the results may have been worse without Siyavula's efforts.

Recent research into educational disadvantage in South Africa has however found that long-term results in Maths and English (international testing regime ie TIMMS and PIRLS) improved slightly from 2006 but have been stagnant since, for all but the highest socio-economic status (SES) quintile. (Taylor, 2017; Taylor \& Yu, 2009) The authors found that disadvantage carried forward from apartheid continues to prevent poorer and even middle-class schools from converting the significant additional resources provided to them in recent years to learning improvement. The challenges of multiple official languages and therefore of learning in non-mother tongue makes learning in South Africa's schools particularly difficult.

Megan explains the challenge of bi-lingual instruction in South Africa, "From Grades 1-3 learners learn in their mother tongue of instruction, and we have 11 official languages. Then in Grade 4, they predominantly switch to English. And now they also have to learn a whole new subject ie. Natural Sciences which starts in Grade 4 at the same time as a new language. It's no wonder kids really battle and start to fall behind at this early stage." Presumably, Grade 4 learners also have to pick up English learning formally, and transition their early maths learning into English.

This is a major challenge and parental or community fluent English speakers due to low levels of the bi-lingual instruction challenge would be hardest to overcome by the poorer regional schools.

However Taylor's recent South African research indicates that even reading levels in mother-tongue language are extremely low, and much investment is first needed in family and school early mother-tongue reading initiatives as a springboard from which reading in English can more effectively be achieved (Taylor, 2017).

Taylor's research echoes Megan's observations about the extra demands of bi-lingualism and the risk of poor schooling outcomes, noting that "If children do not learn to read effectively by Grade 4, they will not cope with curriculum demands in the higher grades. Weak learning foundations, especially in reading, are arguably the main cause of dropping out of school in grades 10, 11 and 12." Taylor's research also confirms that reading well in the earlier grades is strongly predictive of reaching and passing matric, which in turn strongly predicts access and succeed in higher education. In Taylor's earlier studies, many measures of disadvantage were investigated and the lack of textbook or having to share a textbook was found to be a factor for poor English results (Taylor \& Yu, 2009).

Potential for collaborative authoring systems for reading and multi-linguialism

Considering all these factors, then it seems likely that the return on investment in the development of a range of free and low-cost maths and science resources would increase if learners had better base reading skills. 
There are many ways that OER authoring systems could assist improvements in mother-tongue and early English reading, if suitable funders and academic partners could be found. There seems to be a need for additional foundational reading resources - both in the 11 mother-tongue languages as well as in English - that OER collaborative textbook systems could potentially support. Taylor's research also suggests that provision of free English school texts throughout all the years would also assist learners progress to matriculate.

Considering that many South African teachers are also bi-lingual or multi-lingual, Megan notes that another strength of the OER collaborative authoring system is the ability to translate teaching guides back into mother-tongue languages, to be used as support materials for learning the subject in English. Megan notes, "This did happen in one small instance where a group translated our workbooks into isiXhosa to use in some rural schools in the Eastern Cape."

Taylor's research into the importance of parental and adult support for using English would suggest that investing in lifting adult community English and literacy levels across the board may also assist the effectiveness and efficiency of investments in school literacy. The transformational work of Freire's "learning circles" to lift adult literacy level in Brazil may be a model that is useful, as the radical method successfully engaged "peasants" or regional illiterate agricultural workers in areas of great poverty and inequality within 3-5 years (Finn, 1999; Freire, 1994; Gannon, 2017). Other recent global methods to raise community literacies involve programs to distribute free children's books to families for shared reading, and the translation of well-known traditional stories from one language into English to assist bi-lingual learners and families to learn English using known and culturally appropriate texts. OER authoring and publication systems, including cheap e-readers and free online courses might also assist with these efforts as they have done in other bi-lingua contexts, within the context of supportive facilitated local study or discussion groups (Charbonneau-Gowdy, Paula; Capredoni, Rosana; Gonzalez, Sebastian; Jayo, María José; Raby, 2015; Colas, Sloep, \& Garreta-Domingo, 2016).

Indeed, a number of early reading initiatives are emerging in South Africa including "Bookdash" (https://bookdash. org/) which uses a similar collaborative book-sprint model with voluntary authors, illustrators and designers to create new African storybooks that anyone can freely print, translate and distribute. Nali'Bali (https://nalibali.org) focusses on multi-lingual early reading texts, and Fundza (http://www.fundza.co.za ) creates fun, teen-friendly print and electronic books supported by reading groups, lending libraries and lifelong literacy programs.

\section{Conclusion}

This case study has shown that Siyavula developed a sustainable social enterprise business model, ahead of its time, involving a mix of philanthropic, voluntary and commercial resources. Social enterprises in the education sector show it is possible to sell educational tools not to make money, but to subsidise resources and tools for the benefit of learners including those in the under-resourced contexts.

Siyavula leave a strong legacy of the development of multi-stakeholder text-book sprints where an intense face-to-face experience provides the ground-work for a constructive virtual authoring and editing process which is inclusive of diverse stakeholder input across different roles and ranks. Such processes advance curriculum and pedagogy sharing, expertise and capacity building.

Collaborative authoring systems have significant potential not only in South Africa should policy be turned around, but also in other parts of the world. Collaborative authoring systems also have potential beyond the classroom, to support efforts to lift reading and speaking non-mother tongue languages for both adults and children.

Mark notes in conclusion, that "if you just make a text book open and slap an open textbook licence on it, I don't think you fundamentally make it better than before. What makes open great, is that it could be collaboratively authored by a community."

\section{Acknowledgements}

I would like to acknowledge the support of Bea de los Arcos and Martin Weller of the Global OER Graduate Network (GO-GN), for organising and attending the original meeting at Siyavula where this case was seeded, and the whole GO-GN network for their ongoing interest in my research. GO-GN (see www.gogn.org) is an initiative funded by the William and Flora Hewlett Foundation and managed by staff at the Open University of the UK. I would also like to thank Mark Horner and Megan Beckett for participating in this project.

\section{References}

Archer, M. S. (1996). Culture and Agency: The Place of Culture in Social Theory [Revised (2)]. Cambridge: Cambridge University Press.

Archer, M. S. (2003). Structure, Agency and the Internal Conversation. Cambridge: Cambridge University Press.

Atal, Y. (1997). Perspectives on Educating the Poor: Professor R.V. Parulekar Memorial Lectures Delivered at the Indian Institute of Education, Pune. Abhinav Publications. Retrieved from https://books.google.com/ books?id=FwgPc780cyMC\&pgis=1

Case, J. M. (2013). Researching Student Learning in Higher Education: A Social Realist Approach. London: Routledge and the Society for Research into Higher Education. https://doi.org/https://doi. org/10.4324/9780203797402

Ceruti, C. (2011). Maturing Contradictions: the 2010 Public Sector Strike in South Africa Global Labour Column. Retrieved January 22, 2018, from http:// column.global-labour-university.org/2010/01/maturing-contradictions-2010-public.html

Charbonneau-Gowdy, P., Capredoni, R., Gonzalez, S. Jayo, M. J., Raby, P. (2015). Working the Three T's: Teacher Education, Technology and Teacher Identities. In Proceedings of the European Conference on e-Learning, ECEL (pp. 138-146). Academic Conferences Limited. https://doi.org/http://dx.doi. org/10.1108/17506200710779521

Colas, J.-F., Sloep, P. B., \& Garreta-Domingo, M. (2016). The Effect of Multilingual Facilitation on Active Participation in MOOCs. The International Review of Research in Open and Distributed Learning, 17(4), 280314. https://doi.org/http://dx.doi.org/10.19173/ irrodl.v17i4.2470 
Daniel, J. (2014). What Learning for What Development? Journal of Learning for Development - JL4D, 1(1). Retrieved from http://jl4d.org/index.php/ejl4d/article/view/7/3

Devlin, M. (2012). Effective teaching and support of students from low socioeconomic status backgrounds: Practical advice for teaching staff. Australian Learning and Teaching Council. Retrieved from http://www.lowses.edu.au/

Engstrom, C., \& Tinto, V. (2008). Access without support is not opportunity. Change, 40(1), 46-51.

Finn, P. J. (2009). Literacy with an Attitude: Educating Working-Class Children in Their Own Self-Interest (2nd ed.). Albany: State University of New York (SUNY) Press.

Freire, P. (1970). Pedagogy of the Oppressed. London: Penguin Books.

Gannon, K. (2017). Paulo Freire, Pedagogy of the Oppressed, and a Revolutionary Praxis for Education, Part I Age of Revolutions. Retrieved July 20, 2017, from https://ageofrevolutions.com/2017/07/17/paulo-freire-pedagogy-of-the-oppressed-and-a-revolutionary-praxis-for-education-part-i/

Goodier, S. (2017). Tracking the Money for Open Educational Resources in South African Basic Education: What We Don't Know. The International Review of Research in Open and Distributed Learning, 18(4). Retrieved from http://www.irrodl.org/index.php/ irrodl/article/view/2990/4225

Hinchcliff Pearson, S., \& Stacey, P. (2017). Made with Creative Commons. Creative Commons. Retrieved from https://creativecommons.org/made-with-cc/

Hodgkinson-Williams, C., \& Paskevicius, M. (2012). The role of postgraduate students in co-authoring open educational resources to promote social inclusion: a case study at the University of Cape Town. Distance Education, 33(2), 253-269. https://doi.org/10.1080/ 01587919.2012 .692052

Khan, Z.-T. (2017). Google Gives \$20 Million to Nonprofits in Africa for Education. Retrieved November 11, 2018, from https://borgenproject.org/nonprofits-in-africa/

Lambert, S. R. (2018a): History of Siyavula and OER in South African Schools 2002-2017. figshare. Fileset. https://doi.org/10.6084/m9.figshare.7405700.v1

Lambert, S. R. (2018b). Changing our (Dis)Course: A Distinctive Social Justice Aligned Definition of Open Education. Journal of Learning for Development, 5(3), 225-244.

Laurillard, D. (2016). The educational problem that MOOCs could solve: Professional development for teachers of disadvantaged students. Research in Learning Technology, 24(1063519), 1-17. https://doi. org/10.3402/rlt.v24.29369

McKay, J., \& Devlin, M. (2015). "Low income doesn"t mean stupid and destined for failure': challenging the deficit discourse around students from low SES backgrounds in higher education. International Journal of Inclusive Education, 20(4), 347-363. https://doi.org/10.1080/13603116.2015.1079273
Mestan, K., \& Harvey, A. (2013). Increasing School Engagement Through Theme-based Curriculum (Vol. 12, pp. 1-12).

Mountford-Zimdars, A., Sabri, D., Moore, J., Sanders, J., Jones, S., \& Higham, L. (2015). Causes of differences in student outcomes. Retrieved from http://www. hefce.ac.uk/pubs/rereports/Year/2015/diffout/Title,104725,en.html

Munns, G., Sawyer, W., \& Cole, B. (2013). Exemplary Teachers of Students in Poverty. New York: Routledge.

O'Shea, S. (2016). Avoiding the manufacture of "sameness": first-in-family students, cultural capital and the higher education environment. Higher Education, 72(1), 59-78. https://doi.org/10.1007/s10734015-9938-y

Patru, M., \& Balaji, V. (2016). Making Sense of MOOCs: A Guide for Policy-Makers in Developing Countries. Commonwealth of Learning (COL).

Pitt, B., \& Beckett, M. (2014). Siyavula Educator Survey Results: Impact of Using Siyavula (Part IV) - OER Hub. Retrieved November 11, 2018, from http://oerhub. net/collaboration-2/siyavula-educator-survey-results-impact-of-using-siyavula-part-iv/

Selwyn, N. (2013). Distrusting Educational Technology Critical Questions for Changing Times. London: Taylor and Francis.

Siyavula: Building Communities to Support Teacher Use, Localization and Sharing of OER. (2009). Retrieved from https://www.iskme.org/our-work/siyavula-project-formative-and-summative-research-study

Southgate, E., \& Bennett, A. (2016). University Choosers and Refusers: Social Theory, Ideas of "Choice" and Implications for Widening Participation. In M. Shah, A. Bennett, \& E. Southgate (Eds.), Widening Higher Education Participation: A Global Perspective (p. 264). Chandos Publishing.

Stacey, P. (2017). Siyavula. In P. Stacey \& S. Hinchliff Pearson (Eds.), Made with Creative Commons (pp. 125130). Creative Commons. Retrieved from https:// creativecommons.org/made-with-cc/

Taylor, S. (2017, December 11). Improved reading in early grades will transform South Africa. Business Day. Retrieved from https://www.businesslive.co.za/ bd/opinion/2017-12-11-improved-reading-in-early-grades-will-transform-south-africa/

Taylor, S., \& Yu, D. (2009). The importance of socio-economic status in determining educational achievement in South Africa. Stellenbosch Economic Working Papers. Retrieved from http://www.ekon.sun. ac.za/wpapers/2009/wp012009/wp-01-2009.pdf

Thomson, P. (2002). Schooling the Rustbelt Kids: making the difference in changing times. Crows Nest: Allen and Unwin.

Warschauer, M. (2003). Technology and Social Inclusion: Rethinking the Digital Divide. The MIT Press. https:// doi.org/10.1086/381987

Wiley, D., Bliss, T. J., \& McEwan, M. (2014). Open Educational Resources: A Review of the Literature. In M. J. Spector, J.M., Merrill, M.D., Elen, J., Bishop (Ed.), 
Handbook of Research on Educational Communications and Technology (4th ed., pp. 583-590). Springer. https://doi.org/10.1007/978-1-4614-3185-5

Yin, R. K. (2014). Case Study Research Design and Methods. Essential guide to qualitative methods in organizational research (Fifth edit, Vol. 5). Los Angeles: Sage Publications. https://doi.org/10.1097/ FCH.0b013e31822dda9e 